\title{
An Observation on Parenthood of Red-vented Bulbul (Pycnonotus cafer)
}

\section{B. Laxmi Narayana*, K. Swamy, G. Surender, V. Vasudeva Rao}

All India Network project on Vertebrate Pest Management, Professor Jayashankar Telangana State Agricultural University, Rajendranagar, Hyderabad-500 030
Study Area: Professor Jayashankar Telangana State Agricultural University, Rajendranagar, Hyderabad Coordination: $17^{\circ} 19^{\prime} 35.03^{\prime \prime N}$ and $78^{\circ} 24^{\prime} 33.98^{\prime \prime} \mathrm{E}$

Key words: Nest, Perching, Guarding, Crest position .
Introduction:

Red-vented Bulbul (Pycnonotus cafer) is Least Concern species commonly resident in Indian subcontinent. In the present report, some key activities were recorded by using D 9o SLR camera (400 mm lens). The communication posture measurements followed Kumar (2010). Different characteristics and elements of various displays and behaviour were analyzed using photographs. For the measurement of elevation of the crest, a horizontal line was taken over the proximal end of upper mandible and centre of the eye. One vertical line passing through the centre of the eye and the apex of the crest was laid on a horizontal line. The angle was taken according to crest up position and crest down position (o to $5^{\circ}$ Lowest and up to $105^{\circ}$ highest).

Red-vented Bulbul active nest site was spotted on 13th May 2013 in an old building of our University campus campus. On 22nd May 2013, a chick was fallen down from the nest, rescued and placed in the same nest. A total of 43 scan observations were noted during the o9:0o hr to 18:00 $\mathrm{hr}$. Among the recorded activities, parents feeding to chick was high $27.9 \%$ followed by calling $16.3 \%$, moving and perching $14.0 \%$, flying and guarding $9.3 \%$, begging $4.7 \%$ and preening and resting 2.3\% (Table-1). The bird activities such as crest position and angle Down crest position ( $n=9)$, Middle crest position $(n=17)$ and Up crest position $(\mathrm{n}=7)$. The chick was rescued at 09:54 hr and placed back in the nest at 09:59 hr. The parent birds visited the nest at 10:17 hr and flew away with the chick to new location, since many species of birds did not accept to stay in their nest due to predation (Kumar, 2010). In this present observation, a predator bird Spotted Owlet Anthene brama nest was noticed about $15 \mathrm{~m}$ distance from our targeted Red-vented Bulbul nest. During this situation they alerted the chick by giving continuous calls as these birds can scan $275^{\circ}-300^{\circ}$ in the normal position (Kumar 2010; Martin 2007). Begging behaviourwas observed in the chick after the arrival of parents at the new location on the ground. The chick flapped the wings, stretched their neck and begged for the food. The nestling opened their beaks when the parent bird visiting the location with food material. Sometimes, in absence of parents (between two feeding visits), they produced begging calls and other display behaviours which was seen only two times (4.7\%) at 12:21 hrand 12:23 hr.

Table-1: Activity levels of the crest and circumstances in which Pycnonotus cafer performed

\begin{tabular}{|c|c|c|c|c|}
\hline $\begin{array}{l}\text { Crest } \\
\text { position (CP) }\end{array}$ & $\begin{array}{l}\mathrm{CP} \\
\text { angle }\end{array}$ & $\begin{array}{l}\text { Bird } \\
\text { activity }\end{array}$ & $\begin{array}{l}\text { Scan/Ob- } \\
\text { servation*. }\end{array}$ & Proportion \\
\hline $\begin{array}{l}\text { Down crest } \\
\text { position } \\
(n=9)\end{array}$ & $0^{\circ}$ to $30^{\circ}$ & $\begin{array}{l}\text { Begging } \\
\text { Calling } \\
\text { Flying }\end{array}$ & $\begin{array}{l}2 \\
7 \\
4\end{array}$ & $\begin{array}{l}4.7 \% \\
16.3 \% \\
9.3 \%\end{array}$ \\
\hline $\begin{array}{l}\text { Middle crest } \\
\text { position } \\
(\mathrm{n}=17)\end{array}$ & $31^{\circ}$ to $60^{\circ}$ & $\begin{array}{l}\text { Feeding } \\
\text { Guarding } \\
\text { Preening } \\
\text { Moving }\end{array}$ & $\begin{array}{l}12 \\
4 \\
1 \\
6\end{array}$ & $\begin{array}{l}27.9 \% \\
9.3 \% \\
2.3 \% \\
14.0 \%\end{array}$ \\
\hline $\begin{array}{l}\text { Upcrest } \\
\text { position } \\
(n=6)\end{array}$ & $61^{\circ}$ to $105^{\circ}$ & $\begin{array}{l}\text { Perching } \\
\text { Resting } \\
\text { Total }\end{array}$ & $\begin{array}{l}6 \\
1\end{array}$ & $\begin{array}{l}14.0 \% \\
2.3 \% \\
100 \%\end{array}$ \\
\hline
\end{tabular}

( $\mathrm{n}=$ number of observations; ${ }^{*}$-total number $)$

\section{Food \& feeding:}

Feeding behaviour was observed for highest $27.9 \%(\mathrm{n}=12)$ duration at 11:15 hr with earth worm, 11:42 hr, 12:06 hr, 13:00 hr, 13:10 hr, 13:12 hr with neem fruit, 15:18 hr, 16:18 hr, 16:23 hr and 16:27 hr with insect larva. In our observations mostly it fed on Neem fruits (Azadirachta indica) followed byinsect larva's.

Guarding behaviour: Total 9.3\% $(\mathrm{n}=4)$ was observed occasionally by parents to chick at 12:42 hr, 13:25, 16:28 and 16:30 hr. Red-vented bulbuls make cup type nest with small twigs in bushes, sometimes inside houses (Fig.-1). In the present observation, the nest was fallen down and totally disturbed, the parent bird shifted the chick into a concrete hole during 16:28 hr for guarding the chick (Fig.- 

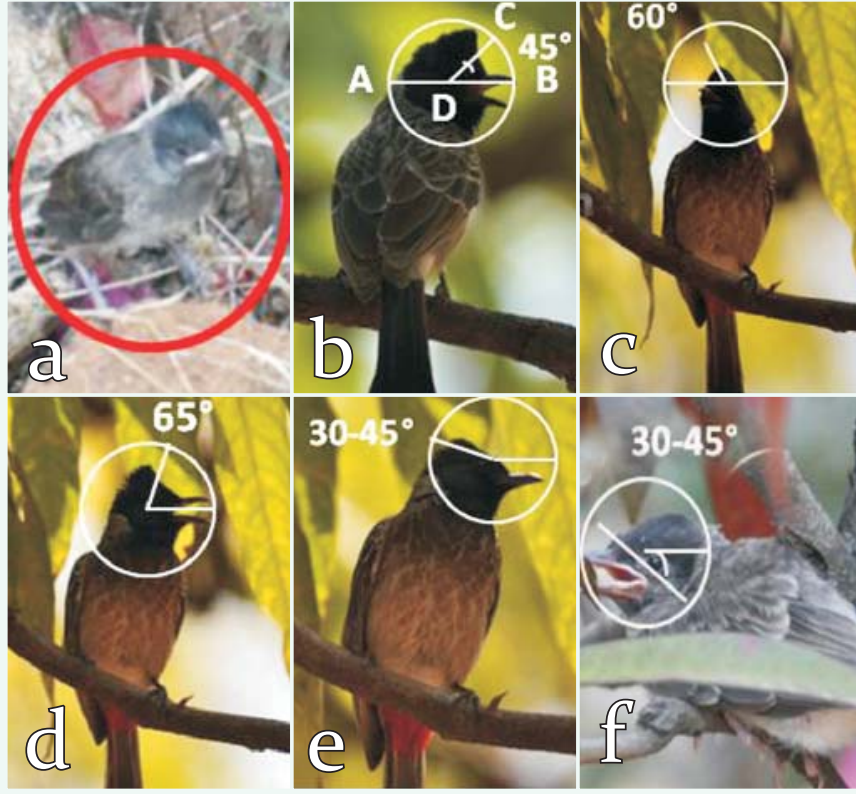

Figure-1: Measurements of angle elevation in relation to different crest levels in which Pycnonotus cafer parent and chick performed various activities (a) chick in the ground, (b-e) feeding, guarding and perching display and (f) begging display. A=Downcrest position; $B=M$ iddle-crest position; $\mathrm{C}=\mathrm{Up}$-crest position; $\mathrm{D}=$ Angle

2). This kind of behaviour was observed for the first time in Red-vented bulbul.

Acknowledgements:

We express our sincere thanks ICAR for providing the financial assistance and PJTS Agricultural University, Hyderabad extended throughout for providing other necessary facilities to carry out the study. We also thankful to the anonymous reviewer for editing the current MS.

\section{References:}

Kumar, A. (2010): Communication value of displays and postures in Red-vented Bulbul Pycnonotus cafer (Aves: Pycnonotidae).J. Threatened Taxa, 2 (6): 919-929.

Martin, G.R. (2007): Visual fields and their functions in birds. J.Ornithol., 148 (2):547-562.

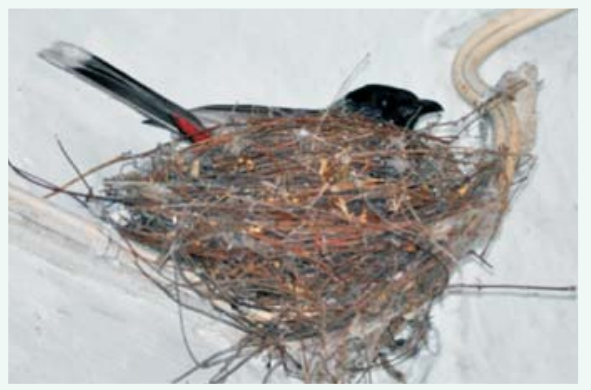

Figure-2: Pycnonotus cafer in the nest site

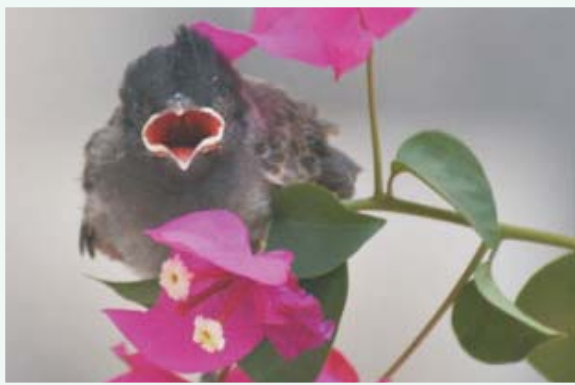

Figure-3: Pycnonotus cafer Chick

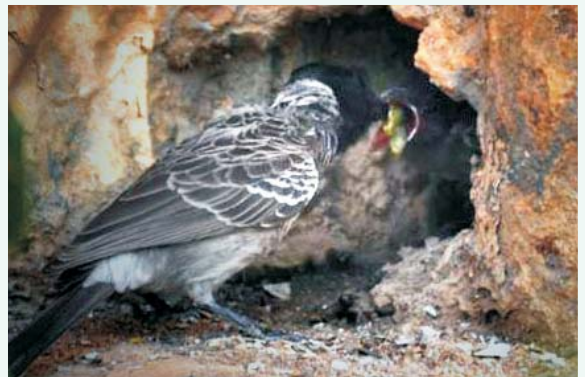

Figure-4: parent Pycnonotus cafer feeding insect larva to chick 